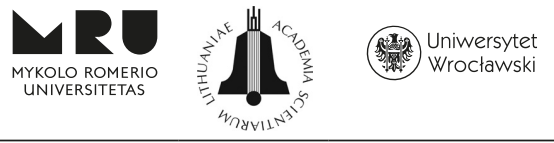

\title{
STOHASTIC AND OPTIMISATION MODELS OF PRICING IN ECO-ECONOMIC SYSTEM
}

\author{
Andrii VERSTIAK \\ Chernivtsi National University \\ E-mail: a.verstyak@chnu.edu.ua \\ Vasyl GRYGORKIV \\ Chernivtsi National University \\ E-mail: emmvsh@gmail.com \\ Mariia GRYGORKIV \\ Chernivtsi National University \\ E-mail: gmvmarichka@gmail.com \\ doi:10.13165/IE-14-8-1-11
}

\begin{abstract}
The nonlinear deterministic and stochastic double-natured models of ecoeconomic balance are offered in this article. The proper deterministic equivalents of stochastic models are built. The constructed models can be used for forecasting price indexes in a multisectoral eco-economic system. The forecast of the price indexes allows controlling the price balances for timely reaction to changes in any constituent of the net output. From the point of view of the decision-making person, it allows optimising the process of pricing prognostication and its dynamics in environmental economics.
\end{abstract}

JEL Classification: C21, C67, C68.

Keywords: environmental economics, pricing, intersectoral balanced models, inputoutput, stochastic model, optimisation model, eco-economic system.

Reikšminiai žodžiai: aplinkos ekonomika, kainodara, tarpsektorinis modelis, tarpšakinio balanso modelis, stochastinis modelis, optimizavimo modelis, ekonominè-ekologiné sistema.

\section{Introduction}

Over the last years, economic growth has been actively implemented in developing countries. For those countries it is very important to provide the projects in economic systems that refer to the problems of the valuable estimation of eco-economic functions in environmental economics. These functions do not have physical forms, so they cannot be taken into account in the pricing forecast process. Such an aspect predetermines the necessity of construction of the methods of pricing including the ecological constituent. 
There is a huge amount of literature on economic development and environmental sustainability. The literature concerns problems of its measurement and implementation in eco-economic and environmental policies. Thus, there is now a widespread interest in the use of Multi-Regional Input-Output Analysis for understanding global environmental problems $[1,2]$. Previous international studies that have estimated final demand induced carbon emissions using IO tables include Cumberland (1966), Ayres and Kneese (1969), Bullard and Herendeen (1975), and Griffin (1976) [3-6]. A number of national statistical agencies and other official bodies in Europe, including Carlsson et al. (2006), Francis (2004), Rormose et al. (2009), Rormose (2010) and the Federal Statistical Office of Germany (2011) and also in Canada, such as Gaston (2011) have produced data for consumption-based emissions using the IO model [7-11].

However, the complexity and diversity of the eco-economic systems and sustainable development require further investigation with the aim of construction new methods (or perfection of the existing ones) for solving socio-economic tasks and saving the natural-resources potential with comprehensive consideration of eco-economic factors in pricing. Therefore, the aim of the article is economic modelling of pricing in ecoeconomic systems with stochastic intersectoral links.

\section{Stochastic model of pricing}

Consider the generalised variant of Leontief-Ford model $[12,13]$ that is written in the form of system of inequations:

$$
\left\{\begin{array}{l}
x_{i}^{(1)} \geq \sum_{j=1}^{n} \varphi_{i j}^{(11)}\left(x_{j}^{(1)}, A_{i j}^{(11)}\right)+\sum_{s=1}^{m} \varphi_{i s}^{(12)}\left(x_{s}^{(2)}, A_{i s}^{(12)}\right)+y_{i}^{(1)}, i=\overline{1, n}, \\
x_{l}^{(2)} \geq \sum_{j=1}^{n} \varphi_{l j}^{(21)}\left(x_{j}^{(1)}, A_{l j}^{(21)}\right)+\sum_{s=1}^{m} \varphi_{l s}^{(22)}\left(x_{s}^{(2)}, A_{l s}^{(22)}\right)-y_{l}^{(2)}, l=\overline{1, m},
\end{array}\right.
$$

де $x^{(1)} \in \mathbb{R}_{+}^{n}$ - vector of total output of main production $\left(\mathbb{R}_{+}^{n}\right.$ - positive orthant of $n$-dimensional vector space);

$x^{(2)} \in \mathbb{R}_{+}^{m}$ - vector of total destroyed industrial contaminant (that total output vector of support sector);

$y^{(1)} \in \mathbb{R}_{+}^{n}$ - vector of final output;

$y^{(2)} \in \mathbb{R}_{+}^{m}$ - vector of undestroyed industrial contaminant;

$\varphi_{i j}^{(11)}\left(x_{j}^{(1)}, A_{i j}^{(11)}\right)$ - function of spending of the good $i$ for producing the good $j$ in number $x_{j}^{(1)}$;

$\varphi_{i s}^{(12)}\left(x_{s}^{(2)}, A_{i s}^{(12)}\right)$ - function of spending of the good $i$ for destroying the contaminant $s$ in number $x_{s}^{(2)}$;

$\varphi_{l j}^{(21)}\left(x_{j}^{(1)}, A_{l j}^{(21)}\right)$ - function of production of the contaminant $l$ during the production process of the good $x_{j}^{(1)}$ in number $j$;

$\varphi_{l s}^{(22)}\left(x_{s}^{(2)}, A_{l s}^{(22)}\right)$ - function of production of the contaminant $l$ during the destroying process of the contaminant $s$, 
$A_{i j}^{(11)}, A_{i s}^{(12)}, A_{l j}^{(21)}, A_{l s}^{(22)}$ - finite set of parameters. All the functions of costs and outputs are nonlinear.

In a meaningful sense, the first $n$ of inequalities (1) show that total output of the main product must be less that we need it to cover all the production expenses and the final output. The sense of the next $m$ inequalities (1) is also obvious - the level of undestroyed pollutants cannot be more than the limit $y_{l}^{(2)}, l=\overline{1, m}$.

Let us assume that $\tilde{x}_{j}^{(1)}$ is the cost of the main good from the sector $j, \tilde{x}_{s}^{(2)}$ is the cost of the destroyed contaminant $s, \tilde{z}_{j}^{(1)}$ is the cost of net output from the main sector $j, \tilde{z}_{s}^{(2)}$ is the cost of net output from the support sector $s$, and $\tilde{\varphi}_{i j}^{(11)}\left(x_{j}^{(1)}, A_{i j}^{(11)}\right), \tilde{\varphi}_{i s}^{(12)}\left(x_{s}^{(2)}, A_{i s}^{(12)}\right)$ and $\tilde{\varphi}_{l j}^{(21)}\left(x_{j}^{(1)}, A_{l j}^{(21)}\right), \tilde{\varphi}_{l s}^{(22)}\left(x_{s}^{(2)}, A_{l s}^{(22)}\right)$ are the appropriate valuable analogues of the above $\operatorname{costs} \varphi_{i j}^{(11)}\left(x_{j}^{(1)}, A_{i j}^{(11)}\right), \varphi_{i s}^{(12)}\left(x_{s}^{(2)}, A_{i s}^{(12)}\right)$ and outputs $\varphi_{l j}^{(21)}\left(x_{j}^{(1)}, A_{l j}^{(21)}\right), \varphi_{l s}^{(22)}\left(x_{s}^{(2)}, A_{l s}^{(22)}\right)$.

Then the double-natured model [13] in valuable form ("by column" for the first and the third quadrant) is formalised by a system of relations:

$$
\left\{\begin{array}{l}
\tilde{x}_{j}^{(1)} \geq \sum_{i=1}^{n} \tilde{\varphi}_{i j}^{(11)}\left(x_{j}^{(1)}, A_{i j}^{(11)}\right)+\sum_{l=1}^{m} \tilde{\varphi}_{l j}^{(21)}\left(x_{j}^{(1)}, A_{l j}^{(21)}\right)+\tilde{z}_{j}^{(1)}, j=\overline{1, n}, \\
\tilde{x}_{s}^{(2)} \geq \sum_{i=1}^{n} \tilde{\varphi}_{i s}^{(12)}\left(x_{s}^{(2)}, A_{i s}^{(12)}\right)+\sum_{l=1}^{m} \tilde{\varphi}_{l s}^{(22)}\left(x_{s}^{(2)}, A_{l s}^{(22)}\right)+\tilde{z}_{s}^{(2)}, s=\overline{1, m} .
\end{array}\right.
$$

The interpretation of the model (2) is also obvious. The first $n$ inequalities show that the total output cannot be less than the costs that we use for the needs of the main activity: production, destroying of pollutants and net output. The next $m$ inequalities show that the cost of destroying pollutants cannot be less than production in the main activity, destroying pollutants that appears during destruction of pollutants and net output from the support sector.

Assume that $p_{j}^{(1)}$ is the price of one $\operatorname{good} j, p_{s}^{(2)}$ is the price of destroying of contaminant $s$ in number $1, k_{j}^{(1)}$ is the coefficient of net output at one good $j$, $\left(\tilde{z}_{j}^{(1)}=k_{j}^{(1)} x_{j}^{(1)}\right)$ or relative price of main product in amount 1 that included in net output from sector $j$ of main production (if $\hat{k}_{j}^{(1)}$ is the portion of good $j$ that was included in net output than $k_{j}^{(1)}=\hat{k}_{j}^{(1)} p_{j}^{(1)}$ and $\left.\tilde{z}_{j}^{(1)}=k_{j}^{(1)} x_{j}^{(1)}=p_{j}^{(1)}\left(\hat{k}_{j}^{(1)} x_{j}^{(1)}\right)\right) ; k_{s}^{(2)}$ is the coefficient of net output from support sector $s\left(\tilde{z}_{s}^{(2)}=k_{s}^{(2)} x_{s}^{(2)}\right)$ or relative price of destroying contaminant $s$ that included in net output from sector $s$ of support production (if $\hat{k}_{s}^{(2)}$ is the portion of the destroyed contaminant that was included in the net output, then $k_{s}^{(2)}=\hat{k}_{s}^{(2)} p_{s}^{(2)} \mathrm{i}$ $\left.\tilde{z}_{s}^{(2)}=k_{s}^{(2)} x_{s}^{(2)}=p_{s}^{(2)}\left(\hat{k}_{s}^{(2)} x_{s}^{(2)}\right)\right)$.

Considering the above assumptions, the system (2) is viewed as follows:

$$
\left\{\begin{array}{l}
p_{j}^{(1)} x_{j}^{(1)} \geq \sum_{i=1}^{n} p_{i}^{(1)} \varphi_{i j}^{(11)}\left(x_{j}^{(1)}, A_{i j}^{(11)}\right)+\sum_{l=1}^{m} p_{l}^{(2)} \varphi_{l j}^{(21)}\left(x_{j}^{(1)}, A_{l j}^{(21)}\right)+k_{j}^{(1)} x_{j}^{(1)}, j=\overline{1, n}, \\
p_{s}^{(2)} x_{s}^{(2)} \geq \sum_{i=1}^{n} p_{i}^{(1)} \varphi_{i s}^{(12)}\left(x_{s}^{(2)}, A_{i s}^{(12)}\right)+\sum_{l=1}^{m} p_{l}^{(2)} \varphi_{l s}^{(22)}\left(x_{s}^{(2)}, A_{l s}^{(22)}\right)+k_{s}^{(2)} x_{s}^{(2)}, s=\overline{1, m}
\end{array}\right.
$$


Dividing the first $n$ equalities of the system (4) appropriately into $x_{j}^{(1)}>0$ and the next $m$ equalities into $x_{s}^{(2)}>0$, we will obtain the following system:

$$
\left\{\begin{array}{l}
p_{j}^{(1)} \geq \sum_{i=1}^{n} p_{i}^{(1)}\left[\varphi_{i j}^{(11)}\left(x_{j}^{(1)}, A_{i j}^{(11)}\right) / x_{j}^{(1)}\right]+\sum_{l=1}^{m} p_{l}^{(2)}\left[\varphi_{l j}^{(21)}\left(x_{j}^{(1)}, A_{l j}^{(21)}\right) / x_{j}^{(1)}\right]+k_{j}^{(1)}, j=\overline{1, n}, \\
p_{s}^{(2)} \geq \sum_{i=1}^{n} p_{i}^{(1)}\left[\varphi_{i s}^{(12)}\left(x_{s}^{(2)}, A_{i s}^{(12)}\right) / x_{s}^{(2)}\right]+\sum_{l=1}^{m} p_{l}^{(2)}\left[\varphi_{l s}^{(22)}\left(x_{s}^{(2)}, A_{l s}^{(22)}\right) / x_{s}^{(2)}\right]+k_{s}^{(2)}, s=\overline{1, m},
\end{array}\right.
$$

or its matrix and vector equivalent:

$$
\left\{\begin{array}{l}
p^{(1)} \geq\left(F^{(11)}\left(x^{(1)}, A^{(11)}\right)\right)^{T} p^{(1)}+\left(F^{(21)}\left(x^{(1)}, A^{(21)}\right)\right)^{T} p^{(2)}+k^{(1)}, \\
p^{(2)} \geq\left(F^{(12)}\left(x^{(2)}, A^{(12)}\right)\right)^{T} p^{(1)}+\left(F^{(22)}\left(x^{(2)}, A^{(22)}\right)\right)^{T} p^{(2)}+k^{(2)},
\end{array}\right.
$$

where $F^{(11)}\left(x^{(1)}, A^{(11)}\right)=\left(\varphi_{i j}^{(11)}\left(x_{j}^{(1)}, A_{i j}^{(11)}\right) / x_{j}^{(1)}\right)_{i, j=1}^{n}$, $F^{(12)}\left(x^{(2)}, A^{(12)}\right)=\left(\varphi_{i s}^{(12)}\left(x_{s}^{(2)}, A^{(12)}\right) / x_{s}^{(2)}\right)_{i, s=1}^{n, m}$, $F^{(21)}\left(x^{(1)}, A^{(21)}\right)=\left(\varphi_{l j}^{(21)}\left(x_{j}^{(1)}, A^{(21)}\right) / x_{j}^{(1)}\right)_{l, j=1}^{m, n}$, $F^{(22)}\left(x^{(2)}, A^{(22)}\right)=\left(\varphi_{l s}^{(22)}\left(x_{s}^{(2)}, A^{(22)}\right) / x_{s}^{(2)}\right)_{l, s=1}^{m}, A^{(11)}, A^{(12)}, A^{(21)}, A^{(22)}$ combined set of appropriate multitude of parameters of the functions in the main and secondary activity.

A system of relations (4) can be called double-natured relatively to prices. In general, it is the system of non-linear equations, namely the generalisation of well-known models $[14,15]$.

The solution of the system (4) depends on $A^{(11)}, A^{(12)}, A^{(21)}, A^{(22)}, x^{(1)}$ and $x^{(2)}$, that is $p^{(1)}=p^{(1)}\left(x^{(1)}, x^{(2)}, A\right), p^{(2)}=p^{(2)}\left(x^{(1)}, x^{(2)}, A\right)$. If the functions of costs and outputs are specifically predefined (setting the numerical values of parameters $A^{(11)}, A^{(12)}, A^{(21)}$, $\left.A^{(22)}\right)$, prices depend only on $x^{(1)}$ and $x^{(2)}$, that is $p^{(1)}=p^{(1)}\left(x^{(1)}, x^{(2)}\right)$, $p^{(2)}=p^{(2)}\left(x^{(1)}, x^{(2)}\right)$. The target value of the desired prices depend on $x^{(1)}$ and $x^{(2)}$, therefore $p^{(1)}=p^{(1)}\left(x^{(1)}, x^{(2)}\right), p^{(2)}=p^{(2)}\left(x^{(1)}, x^{(2)}\right)$ thus, we should firstly determine $x^{(1)^{*}}$ and $x^{(2)^{*}}$. Thereafter, we must place $x^{(1)^{*}}$ and $x^{(2)^{*}}$ into model (4) and determine the solution $p^{(1)^{*}}=p^{(1)}\left(x^{(1)^{*}}, x^{(2)^{*}}\right), p^{(2)^{*}}=p^{(2)}\left(x^{(1)^{*}}, x^{(2)^{*}}\right)$.

Model (4) can be written in the following form:

$$
p \geq F^{T}(x, A) p+k,
$$

where $p=\left(p^{(1)}, p^{(2)}\right)^{T}, k=\left(k^{(1)}, k^{(2)}\right)^{T}, x=\left(x^{(1)}, x^{(2)}\right)^{T}, A=A^{(11)} \cup A^{(12)} \cup A^{(21)} \cup A^{(22)}$, 


$$
F^{T}(x, A)=\left(\begin{array}{ll}
\left(F^{(11)}\left(x^{(1)}, A^{(11)}\right)\right)^{T} & \left(F^{(21)}\left(x^{(1)}, A^{(21)}\right)\right)^{T} \\
\left(F^{(12)}\left(x^{(2)}, A^{(12)}\right)\right)^{T} & \left(F^{(22)}\left(x^{(2)}, A^{(22)}\right)\right)^{T}
\end{array}\right)
$$

or as follows:

$$
B(x, A) p \leq d,
$$

where $\tilde{F}\left(t_{i}(x)\right), \tilde{F}(\tau)=0,5+\Phi(\tau), \tilde{F}\left(t_{i}(x)\right) \geq \alpha$ - single diagonal matrix with dimension $(n \times n)$ and $(m \times m)$.

Now we assume that the components of vector $d$ and the parameters of the model (4) (that are in multitude $A$ ) depend on elementary event of probability space, where $\Omega$ - space of elementary events, $S$ - algebra of events, $P$ - probability of function that defined on algebra $S$.

The existence of random effects on parameters of model (5) can violate its conditions, thus from model (5) we go to its stochastic analogue:

$$
\left\{\begin{array}{c}
P\{B(x, A(\omega)) p \leq d(\omega)\} \geq \alpha \\
\omega \in \Omega
\end{array}\right.
$$

where \{\} - probability of an appropriate event, $\alpha$ - predefined minimum value of probability (level of significance $\alpha$ is approximate to 1 ).

\section{Deterministic equivalent of stochastic model of pricing}

Model (6) cannot be solved directly, thus a traditional scheme of investigation of such a model is based on the construction of determined equivalents $[16,17]$.

Let us consider that all the elements of the set $A(\omega)$ (and appropriate elements of matrix $B(x, A(\omega))$ and vector $d(\omega))$ are mutually independent and are normally statistically distributed variables with expectations $M\left(b_{i j}(x, A(\omega))\right)=\overline{b_{i j}}(x)$, $M\left(d_{i}(\omega)\right)=\bar{d}_{i}$ and variance $\sigma^{2}\left(b_{i j}(x, A(\omega))\right)=\sigma_{i j}^{2}(x), \sigma^{2}\left(d_{i}(\omega)\right)=\theta_{i}^{2}$.

Then the difference $\left(\sum_{j=1}^{n+m} b_{i j}(x, A(\omega)) p_{j}-d_{i}(\omega)\right)$ will also have normal distribution and $M\left(\sum_{j=1}^{n+m} b_{i j}(x, A(\omega)) p_{j}-d_{i}(\omega)\right)=\sum_{j=1}^{n+m} \bar{b}_{i j}(x) p_{j}-\bar{d}_{i}$, $\sigma^{2}\left(\sum_{j=1}^{n+m} b_{i j}(x, A(\omega)) p_{j}-d_{\nu}(\omega)\right)=\sum_{j=1}^{n+m} \sigma_{i j}^{2}(x) p_{j}+\theta_{i}^{2}$.

Taking into consideration the above,

$$
P\left\{\sum_{j=1}^{n+m} b_{i j}(x, A(\omega)) p_{j} \leq d_{i}(\omega)\right\}=P\left\{\sum_{j=1}^{n+m} b_{i j}(x, A(\omega)) p_{j}-d_{i}(\omega) \leq 0\right\}=
$$




$$
\begin{aligned}
& =P\left\{\left[\sum_{j=1}^{n+m} b_{i j}(x, A(\omega)) p_{j}-d_{i}(\omega)\right]-\left[\sum_{j=1}^{n+m} \bar{b}_{i j}(x) p_{j}-\bar{d}_{i}\right]+\left[\sum_{j=1}^{n+m} \bar{b}_{i j}(x) p_{j}-\bar{d}_{i}\right] \leq 0\right\}= \\
& =P\left\{\frac{\left[\sum_{j=1}^{n+m} b_{i j}(x, A(\omega)) p_{j}-d_{i}(\omega)\right]-\left[\sum_{j=1}^{n+m} \bar{b}_{i j}(x) p_{j}-\bar{d}_{i}\right]}{\left(\sum_{j=1}^{n+m} \sigma_{i j}^{2}(x) p_{j}^{2}+\theta_{i}^{2}\right)^{1 / 2}} \leq \frac{\bar{d}_{i}-\sum_{j=1}^{n+m} \bar{b}_{i j}(x) p_{j}}{\left(\sum_{j=1}^{n+m} \sigma_{i j}^{2}(x) p_{j}^{2}+\theta_{i}^{2}\right)^{1 / 2}}\right\} \equiv \\
& \equiv P\left\{\eta_{i}(x) \leq t_{i}(x)\right\}=\tilde{F}\left(t_{i}(x)\right) \geq \alpha, \quad i=1, n+m .
\end{aligned}
$$

In formula (7) $\tilde{F}\left(t_{i}(x)\right)$ - function of normalised normal distribution that turns on $x$, moreover $\tilde{F}(\tau)=0,5+\Phi(\tau)$, where $\Phi(\tau)$ is function Laplace [17].

As the distribution function is not decreasing, inequality $\tilde{F}\left(t_{i}(x)\right) \geq \alpha$ I performed when коли $t_{i}(x) \geq t_{i}^{(\alpha)}$, where $t_{i}^{(\alpha)}=\tilde{F}^{-1}(\alpha)=\Phi^{-1}(\alpha-0,5), i=\overline{1, n+m}$. We can consider also a more general situation, when the elements of the set $A(\omega)$ and vector $d(\omega))$ are not normally statistically distributed variables. It is very important in this case that all elements are mutually independent. Moreover, the level of significance should not be the same for all the inequalities of the system.

The analysis of inequalities $t_{i}(x) \geq t_{i}^{(\alpha)}$ and (7) leads us to the deterministic equivalent of the stochastic model (6) that is formalised by the system of inequalities:

$$
\sum_{j=1}^{n+m} \overline{b_{i j}}(x) p_{j}+t_{i}^{\alpha}\left(\sum_{j=1}^{n+m} \sigma_{i j}^{2}(x) p_{j}^{2}+\theta_{i}^{2}\right)^{1 / 2} \leq \bar{d}_{i}, i=1, \overline{n+m} .
$$

System (8) is a non-linear system that depends on the parameters, it is therefore very hard to find its solution in explicit analytical form. Fixing the parameter $x$, we will obtain the system without parameters and for its solving we can use the well-known methods of solving the non-linear systems, in particular to lead it down to the system of equalities and to solve one by numerical methods $[18,19]$.

In particular, the solution of the system of inequalities (8) can be started from leading it down to the task of MP:

$$
\left\{\begin{array}{c}
\sum_{j=1}^{n+m} v_{j} \rightarrow \min , \\
\sum_{j=1}^{n+m} \overline{b_{i j}}(x) p_{j}+t_{i}^{(\alpha)}\left(\sum_{j=1}^{n+m} \sigma_{i j}^{2}(x) p_{j}^{2}+\theta_{i}^{2}\right)^{1 / 2}+w_{i}+v_{j}=\bar{d}_{i}, i=1, \overline{n+m}, \\
x, w, v \in \mathbb{R}_{+}^{n+m},
\end{array}\right.
$$

where $w$ - vector of auxiliary variables, $v$ - vector of artificial variable. After specifying the vector of parameters $x$ and solving the task (9), we will get the solution of (8) (namely the vector of prices $p^{*}$ ). 


\section{Optimisation model of pricing}

In addition to the above approaches of forecast prices in eco-economic system based on the use of deterministic models and stochastic modifications, we can also suggest approaches that use optimisation models.

Thus, the feasible set of deterministic and stochastic optimisation models can be the set of prices that are described in the forms (5) and (6), possibly with some additional restrictions. To formalise such models, we need to define a function that exists as a criterion of development of an eco-economic system. This criterion cannot be the only one, i.e. optimisation model can be based on multiple criteria, although in most cases we can build a sufficiently grounded (in the economic sense) one integral criterion on the basis of several criteria and reduce the multicriteria model to a 'one criteria' task.

On the base of the analysis of (1) i (5), we can propose one of the criteria and the appropriate utility function. As the vector of final output $y^{(1)}$ is the principal aim of the main activity, the maximisation of its cost, obviously, is the one economic criterion $\left(f^{(1)}(p(x, A))=\left\langle y^{(1)}, p^{(1)}(x, A)\right\rangle \rightarrow \max\right.$, where $\langle\cdot\rangle$ - non-vector product $)$.

The criteria representing the aim of secondary activity is the minimisation of cost for the destruction of pollutants $\left(f^{(2)}\left(p(x, A)=\left\langle x^{(2)}, p^{(2)}(x, A)\right\rangle \rightarrow \min \right)\right.$.

Simultaneous maximisation of the function $f^{(1)}(p(x, A))$ and minimisation of the function $f^{(2)}(p(x, A))$ actually lead us to 'one criteria' maximisation of the function.

$$
f(p(x, A))=f^{(1)}(p(x, A))-f^{(2)}(p(x, A)) .
$$

Adding to relation (5) the condition of no negativity of the prices we will obtain one of the deterministic optimistional pricing models.

\section{Conclusions}

The constructed models can be used for forecasting price indexes in a multisectoral eco-economic system. The forecasts of the price indexes allows controlling the price balances and timely reaction to changes in any constituent of the net output. From the point of view of the decision-making person, it allows optimising the process of pricing and its dynamics in environmental economics.

The information system of uniting pricing tasks in the ecologically balanced economy is created with the kit of visual resources for empirical analysis of developed economicmathematical models and is used in experimental researches and monitoring tasks.

\section{References}

1. Wiedmann, T. (2009) A Review of Recent Multi-Region Input-Output Models used for Consumption-Based Emissions and Resource Accounting. Ecological Economics, vol. 69 , p. $211-222$. 
2. Wiedmann, T.; Lenzen, K. Turner and Barrett, J. (2007) Examining the Global Environmental Impact of Regional Consumption Activities - Part 2: Review of Input-Output Models for the Assessment of Environmental Impacts Embodied in Trade. Ecological Economics, vol. 61, p. 15-26

3. Cumberland, J.H. (1966) "A Regional Interindustry Model for Analysis of Development Objectives", Papers in Regional Science, Vol. 17, No. 1, p. 65-94

4. Ayres, R.U. and Kneese, A.V. (1969) "Production, Consumption, and Externalities", The American Economic Review, Vol. 59, No. 3, p. 282-297.

5. Bullard, C.W. and Herendeen, R.A. (1975) "The energy cost of goods and services", Energy Policy, Vol. 3, No. 4, p. 268-278.

6. Griffin, J. (1976) “Energy Input-Output Modelling: Problems and Prospects”, Palo Alto: Electric Power Research Institute.

7. Carlsson, A.; Palm, B. and Wadeskog, A. (2006) "Energy use and CO2-emissions for consumed products and services. IPP-indicators for private and public consumption based on environmental accounts" Environmental Accounts, Statistics Sweden, 2006.

8. Francis (2004) "The impact of UK households on the environment through direct and indirect generation of greenhouse gases", Office for National Statistics, Grant Agreement No. 200141200010.

9. Rormose, P.; Olsen, T. and Hansen, D. (2009) "GHG Emissions Embodied in Trade", Statistics Denmark, Grant agreement No. 50304.2008.00.

10. Federal Statistical Office of Germany (2011) "Extended Input-Output Model for Energy and Greenhouse Gases”, Ref. No. 50304.2009.001 - 2009.249.

11. Gaston, C (2011) "Consumption-related greenhouse gas emissions in Canada, the United States and China", Service bulletin EnviroStats, Vol. 5, No. 4, p. 14-21.

12. Leontief, W. \& Ford, D. (1970) Environmental repercussions and the economic structure: An input-output approach, Review of Economics and Statistics, vol. 52, p. $262-271$

13. Grygorkiv, V. Stochastic model of pricing in eco-economic system // In the proceedings of the IV international conference "The theory of decision making". - Uzhorod, 2008. - p. 71-72.

14. Grygorkiv, V. Environmental economic modeling. - Chernivtsi, 2007, p. 74-75.

15. Grygorkiv, V; Verstiak, A. The prognostication of the prices on the base of linear Leontief-Ford Model // Lviv national university scientific journal. - Lviv: 2007, vol. 16., p. 61-68.

16. Grygorkiv, V. S. and Biloskurskii, R. R. Some stochastic Leontief-Ford models and their deterministic equivalents. Cybernetics And Systems Analysis, Volume 43, Number 3 (2007), 315-320, DOI: 10.1007/s10559-007-0051-9, http://www.springerlink.com/content/16874062u13028pn/ (accessed in September 2012).

17. Gluhov, V.V; Mednikov, M.D.; Korobko, S.D. Mathematical methods and models in management, 2000, p. 125-138.

18. Bahvalov, N.S. Numerical methods, 1975, p. 432-453.

19. Samarskiy, A.A.; Gulin, A.V. Numerical methods, 1989, p. 25-31. 


\section{KAINODAROS STOCHASTINIAI IR OPTIMIZAVIMO MODELIAI APLINKOS EKONOMIKOS SISTEMOJE}

Santrauka. Straipsnyje yra pasiūlytas netiesinis deterministinis ir stochastinis dviejų dalių ekologinio ir ekonominio balanso modelis. Pasiūlyti tinkami stochastinių modelių determinantai. Parengti modeliai gali būti panaudojami kainų indeksų prognozavimui daugiašakiniame ekologiniame-ekonominiame modelyje. Kainų indeksų prognoze leidžia kontroliuoti kainų pokyčius ir laiku reaguoti $\mathfrak{i}$ grynosios produkcijos sudedamųjų dalių pokyčius. Galima panaudoti priimant sprendimus bei leidžia optimizuoti kainų prognozavimą ir sekti jo dinamiką aplinkos ekonomikos sistemoje.

Andrii VERSTIAK - Chernivtsi National University, Ukraine, Department of Economics, $\mathrm{PhD}$, Associate Professor.

Research interests: mathematical and quantitative methods in environmental economics.

Andrii VERSTIAK - Ekonomikos katedros mokslų daktaras, docentas. Chernivtsi nacionalinis universitetas, Ukraina.

Mokslinių interesų sritys: matematikos ir kiekybinių metodų taikymas aplinkos ekonomikoje.

Vasyl GRYGORKIV- Prof. Dr., Chernivtsi National University, Ukraine, Department of Economics.

Research interests: mathematical and quantitative methods in environmental economics.

Vasyl GRYGORKIV- Ekonomikos katedros mokslų daktaras, profesorius. Chernivtsi nacionalinis universitetas, Ukraina.

Mokslinių interesų sritys: matematikos ir kiekybinių metodų taikymas aplinkos ekonomikoje.

Mariia GRYGORKIV - Research assistant, Chernivtsi National University, Ukraine, Department of Economics.

Research interests: mathematical and quantitative methods.

Mariia GRYGORKIV - Ekonomikos katedros tyrèja, Chernivtsi nacionalinis universitetas, Ukraina.

Mokslinių interesų sritys: matematika ir kiekybiniai metodai. 